\title{
Design Waypoint Drone Hexacopter Model Using Sugeno Fuzzy Logic
}

\author{
Akhmad Khoirunnas a,1,* Jainur Rohman a,2, Imam Ashar a,3 \\ a Politeknik Angkatan Darat, Malang, Indonesia \\ ${ }^{1}$ kommil2505@gmail.com*; ${ }^{2}$ kommil2505@gmail.com; ${ }^{3}$ kommil2505@gmail.com \\ * corresponding author
}

Keywords Fuzzy Logic Waypoint Drone GPS

\begin{abstract}
Fuzzy logic is a scientific branch of Artificial Intelligence that was developed and applied to machines to be able to approach human intelligence. In order this machine or tool to be able to execute commands in a "more humane" manner, this AI uses a rule base as a reference for movement which then goes into the defuzzyication process. To apply the fuzzy logic rule base on the drone movement automatically, an error value is taken at tetta $(\theta)$ which was previously processed by the Odometery Method by taking the position value of the drone with GPS. In addition, the drone is also monitored through Android in realtime so that the user can see the position and set the goals of the drone. In order for the processor and realtime process to run optimally, the drone will use Arduino Mega as a processor, control center, and read input from each sensor related to the drone before entering FireBase (Cloud Data Base). Control of the stability of the drone system in the air is obtained by processing GPS sensors with the fuzzy logic method with an error at reading of coordinate is 0,4 meter from line distance that is given and response acceleration of fuzzy to reset the drone back to the distance of $4 \mathrm{~m} / \mathrm{s}$.
\end{abstract}

\section{Introduction}

Of the many studies, unmanned aerial vehicles or commonly called UAV (Unmanned Aerial Vehicles) become one of the priority areas of development. This is due to considerations in terms of functionality that is very diverse and applicable to various needs. UAV is an unmanned system, which is an electro-mechanical based system that can carry out programmatic missionary characteristics with a flying machine that functions with remote control by a pilot or can control itself, using aerodynamic laws to lift itself, can be reused and reused able to carry both weapons and other cargo. UAV has many types, one of which is hexacopter, UAV hexacopter can hover (float) at one point (point) so it can easily in terms of operation and the controlling in areas difficult. There are two main variations in unmanned aircraft control, the first variation is controlled by remote control and the second variation is an aircraft that is flying independently based on the program that is entered into the aircraft before flying. The process of aircraft control is entirely carried out by the Waypoint system regarding parameters that have been determined by the user before flying. One of them is the fuzzy logic method in implementation the Waypoint mode. Fuzzy Logic is a branch of Artificial Intelligence that was developed and applied to machines to approach human intelligence[1][2][3]. In other words, fuzzy logic has the function of "mimicking" the intelligence of humans to do something and implementing it to a device, such as a hexacopter drone.

In order Hexacopter to run smoothly and accurately, the writer tries to use the Arduino Mega microcontroller as a controller to be more powerful in data processing[4] [5][6], Fuzzy Logic Sugeno as the data processor and Android as the data sender and the movement monitor of the Drone Hexacopter.

The drone will be controlled automatically using fuzzy logic, it does not move with a boolean value that uses a value of 0 or 1 to make decisions, but instead uses an approach set based on the rule base membership value of the fuzzy logic method[4]. 


\section{The Proposed Method/Algorithm}

\subsection{System Architecture Schema}

Block output is part of the system that is in charge of running the system by following function equipment is designed, based on the condition of which is given by the blocking process. Schema modeling tool as in Fig.1.

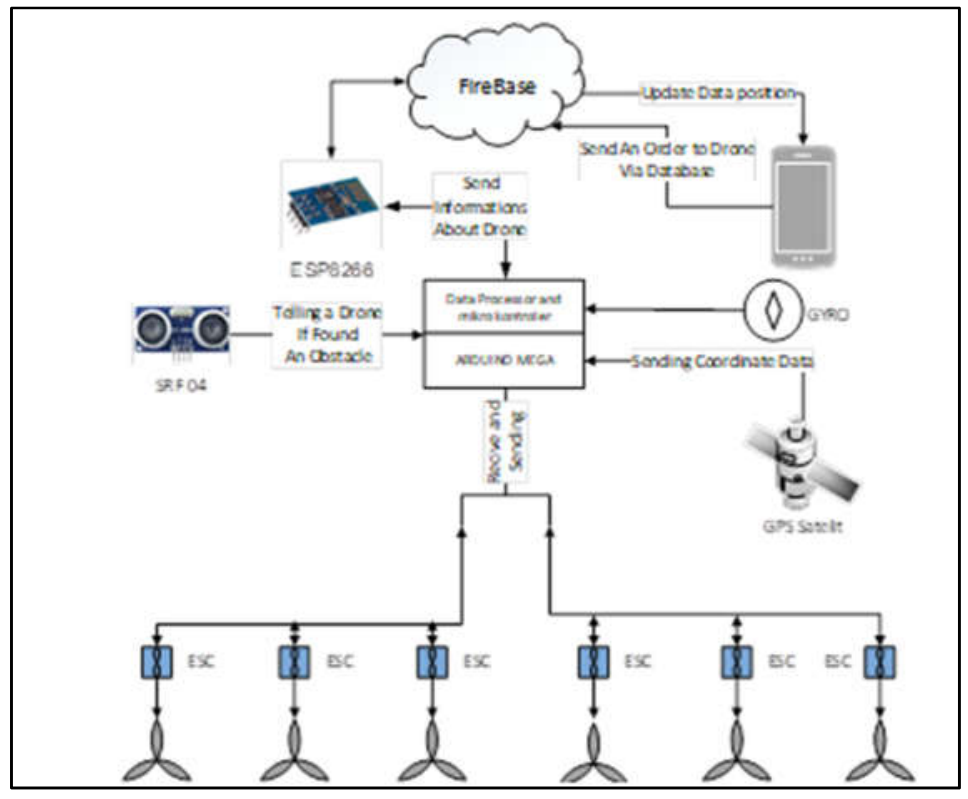

Fig. 1. Block diagram of the system architecture scheme

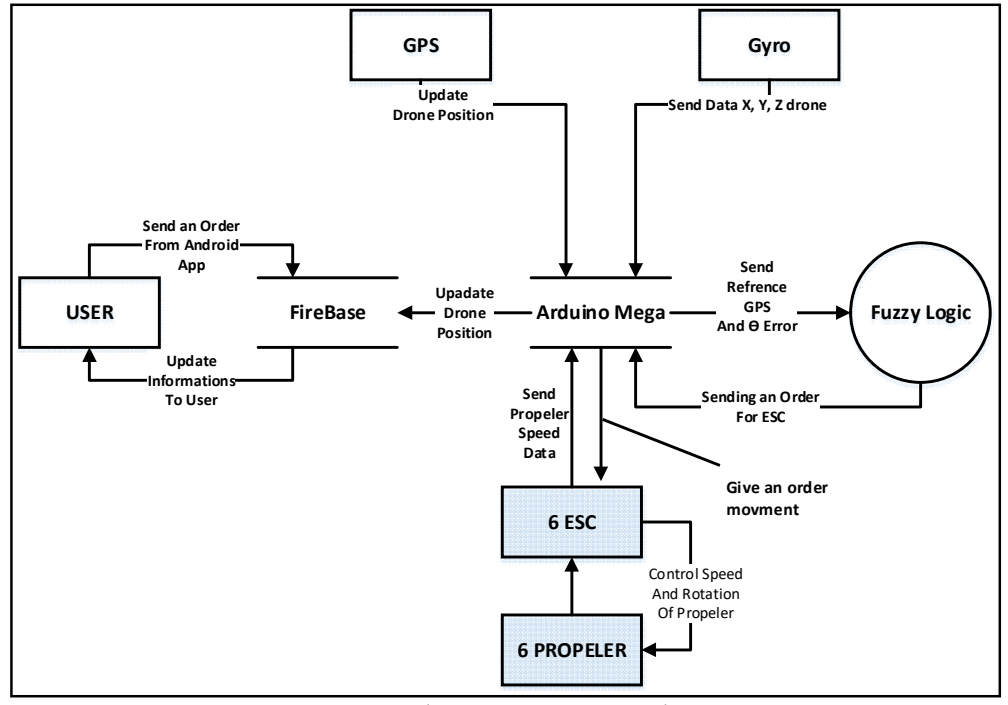

Fig. 2. Flow Dagram Tools

The working principle of a whole series of tools that have been assembled into a series of mutual support systems so that equipment is designed to work actively for the functions that have been planned. The system described tool works created through labor system flow diagram tool in Fig. 2 and explanations flow diagram tool working system is as follows:

- Mode Waypoint (autonomous) drones will determine coordinates, height, speed, and stability required in autonomous mode through the odometry system. 
- The location drone obtained an initial position from the odometry system will be in fuzzification to determine decision-making so that the drones remain at setpoint until the destination coordinates.

- When telemetry RX received the order, it will be received by the sensor and initialization to Arduino to run each motor and propeller that exist in hexacopter drones

\subsection{Design of Common Device Hardware}

The design of the tool in the form of the device hardware of drone hexacopter such as that shown in Fig. 3 and Fig. 4.

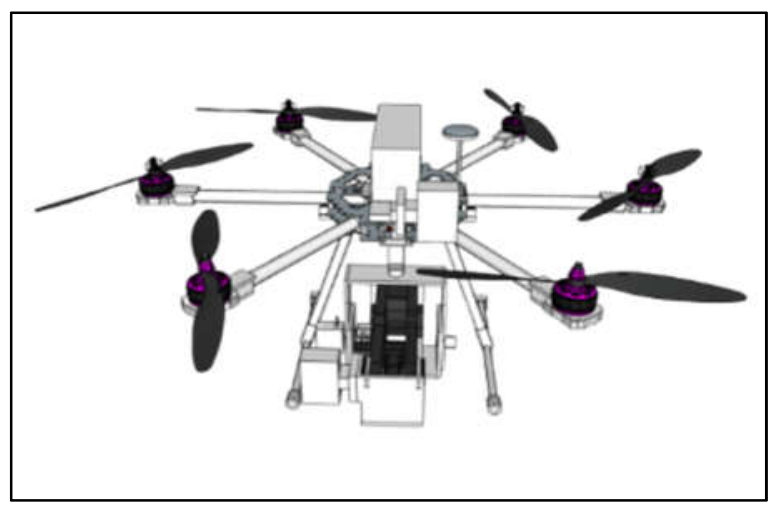

Fig. 3. Design Tools Hardware of the Drone Hexacopter (front)

Fig. 3 and fig. 4 are planning the design of device hardware drone hexacopter by controlling the autonomous use of fuzzy logic

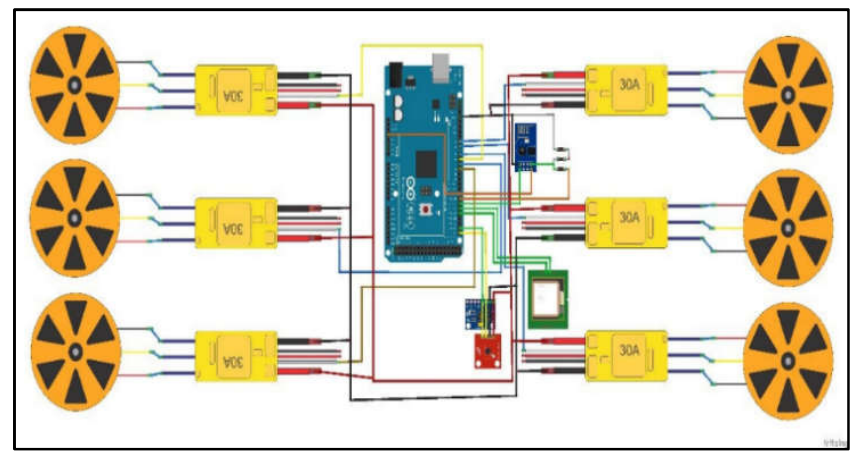

Fig. 4. Input and Output of Arduino Mega 2560

Below explained the pins used on the Arduino Mega 2560 microcontroller for input and output control[7], namely (1) The PWM 4 - 9 port on Arduino will be used as communication with the ESC sensor, (2) Port 14 (TX3) Arduino is connected to the RXD port on ESP8266, used as a transmitter to ESP8266, (3) Port 15 (RX3) Arduino is connected to the TXD port on ESP8266, used as a receiver of ESP8266, (4) Port 16 (TX2) Arduino is connected to the RX port on the GPS sensor, used as a transmitter to the GPS sensor, (5) Port 15 (RX2) Arduino is connected to the TX port on the GPS sensor, used as a receiver of the GPS sensor, (6) Port 20 Arduino is connected to the SDA port of Gyro and Compass sensors, (7) Port 21 Arduino is connected to the Gyro and Compass sensor SCL ports. 


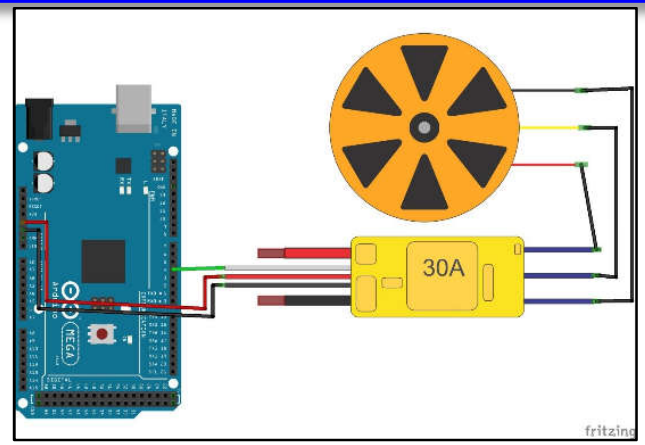

Fig. 5. The Design of Electronics Speed Control

This is the relations ports of the ESC sensor with Arduino Mega is PWM port 4-9 on Arduino will be used as the communication with the ESC sensor.

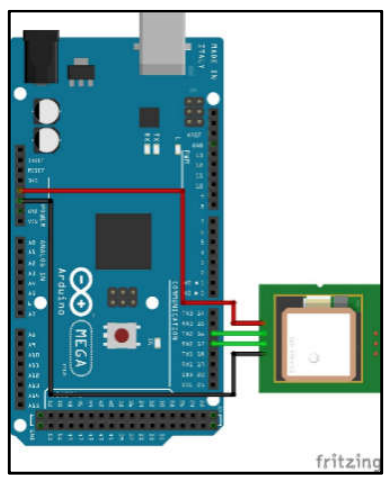

Fig. 6. The Design of GPS Module

There are ports relation of the GPS sensor with Arduino Mega is as follows: (1) Pin Vin: Connected to Pin 5 V Arduino, (2) GND Pin: Connected to Ground, (3) RX Port The GPS sensor is connected to the TX2 port on Arduino, (4) TX Port The GPS sensor is connected to the RX2 port on Arduino.

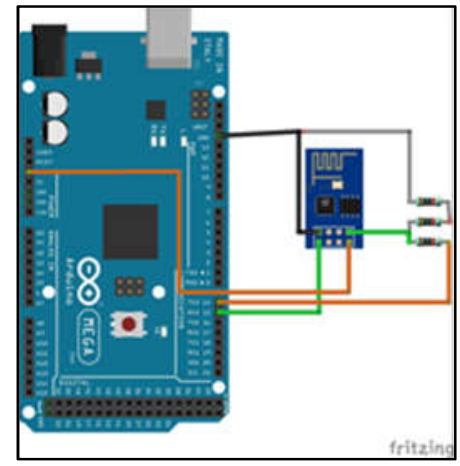

Fig. 7. ESP Module Wiring Series on the Microcontroller

Based Fig.7 port 15 (RX3) Arduino is connected to the TXD port on ESP8266, used as a receiver of ESP8266. Relationships ports on Gyro Sensor with Arduino Mega is as follows: (1) The SCL port will send data to Arduino via port A5, (2) The SDA port will send data to Arduino via the A4 port, (3) The VDD port is connected to a 5V voltage, (4) GND Port is connected to Ground. 


\subsection{Design of Android Application}

Android application design making this tool functioning android application required to enter the destination coordinate values and to display the map position of the movement of the drone. Application design hexacopter drone Waypoint mode uses language development Java with Android Studio. Layout view layout or applications located in the folder res/layout in a project folder. Layout applications are organized in a hierarchical format XML based on the components contained in the application can be seen in Fig. 8.

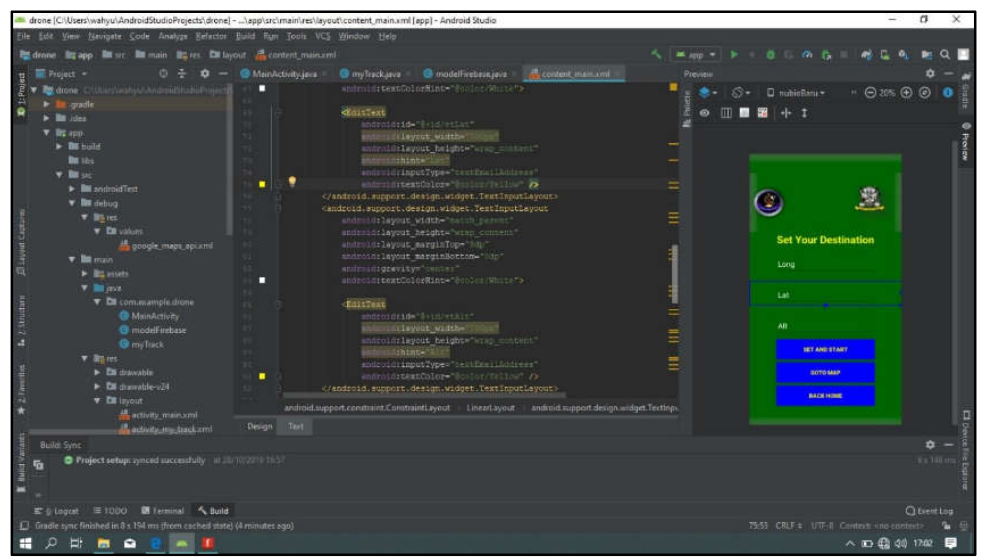

Fig. 8. Android Application Development Using Android Studio

\section{Method}

The fuzzification process, the drone will decide on Waypoint mode for setting stability, altitude, and speed to fly to the destination by reading the location of the drone through the odometry[8]. The system image will be described in the flow diagram of the control system show on Fig. 9.

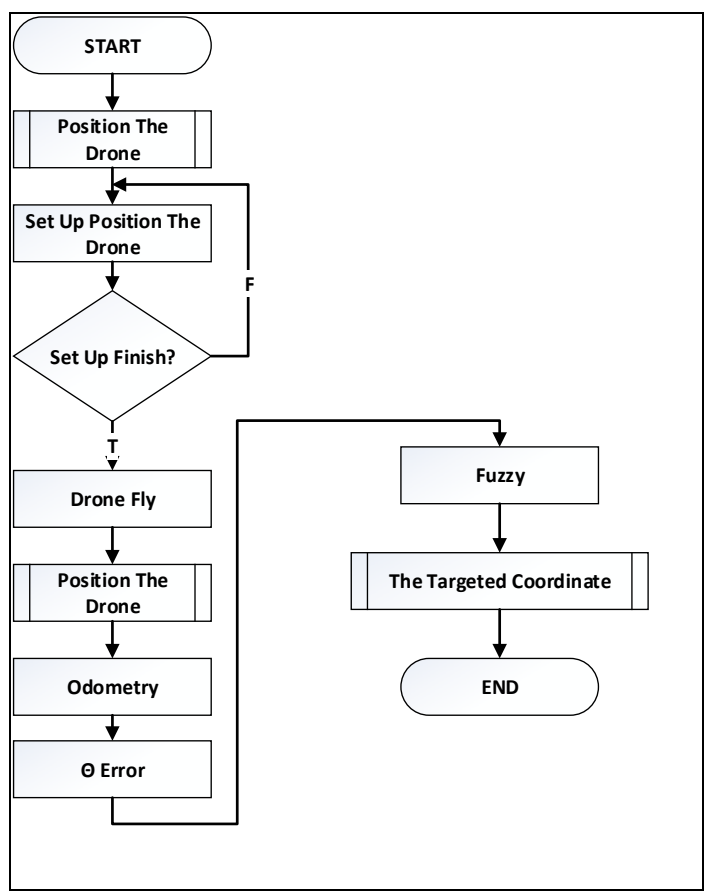

Fig. 9. Flowchart of the Control

Software design is the design language of the program that will be included or embedded in the drone hexacopter the method of fuzzy logic using rules and implications. The implication is a way to 
express the rule. Suppose given composition rule A and rule B, then the implication is expressed in: Zero-Order[2], The general form:

IF ( $\mathrm{X}$ is $\mathrm{A})(\mathrm{X}$ is $\mathrm{A})(\mathrm{X}$ is $\mathrm{A})(\mathrm{X}$ is $\mathrm{A})$ THEN $\mathrm{z}=\mathrm{k}$ Ai is set to the fuzzy-I as an antecedent, and $\mathrm{k}$ is a constant (firm) as consistent.

Order-one General Shape:

IF ( $\mathrm{X}$ is $\mathrm{A}$ ) .... ( $\mathrm{X}$ is $\mathrm{A}$ ) THEN $\mathrm{z}=\mathrm{p}$ with $\mathrm{Ai}$ is the set of fuzzy-I as an antecedent to, and pi is a constant to-I and $q$ are constants in the consequent.

Sugeno use constants or a mathematical function of the input variables:

IF $\mathrm{X}$ is $\mathrm{A} A N D \mathrm{Y}$ is $\mathrm{B}$ Then $\mathrm{Z}$ is $\mathrm{K}$

where $\mathrm{x}, \mathrm{y}$ and $\mathrm{z}$ are linguistic variables; $\mathrm{A}$ and $\mathrm{B}$ are fuzzy set for $\mathrm{X}$ and $\mathrm{Y}$, and $\mathrm{f}(\mathrm{x}, \mathrm{y})$ is a mathematical function. The process mechanism of fuzzy logic can be seen in Fig. 10 to Fig. 13.

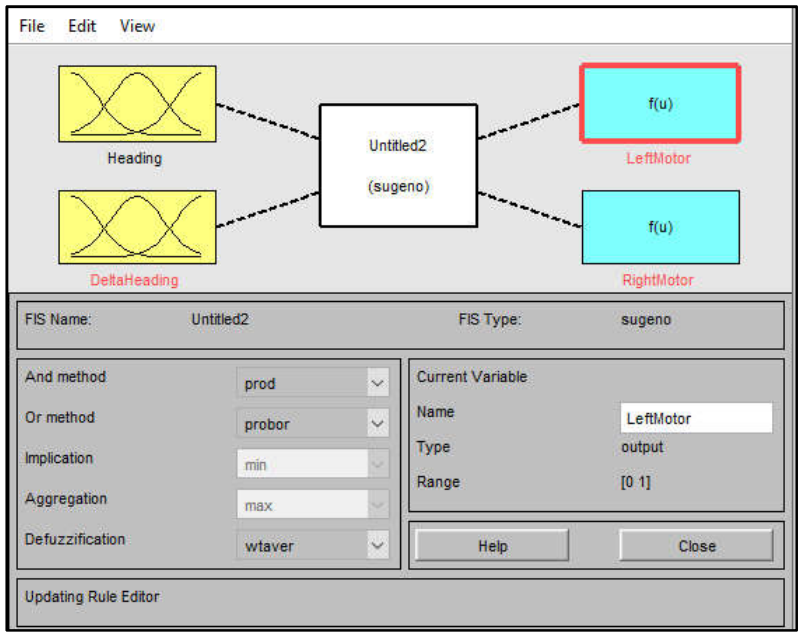

Fig. 10. Fuzzy Logic Parameters

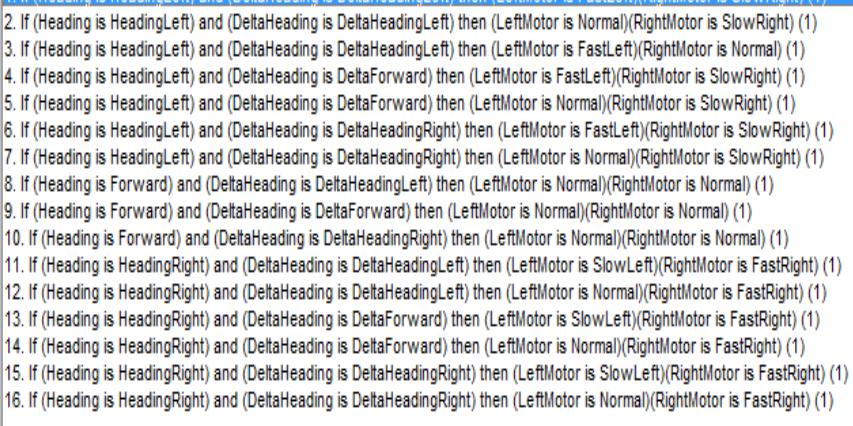

Fig. 11. Rule of Fuzzy Control 


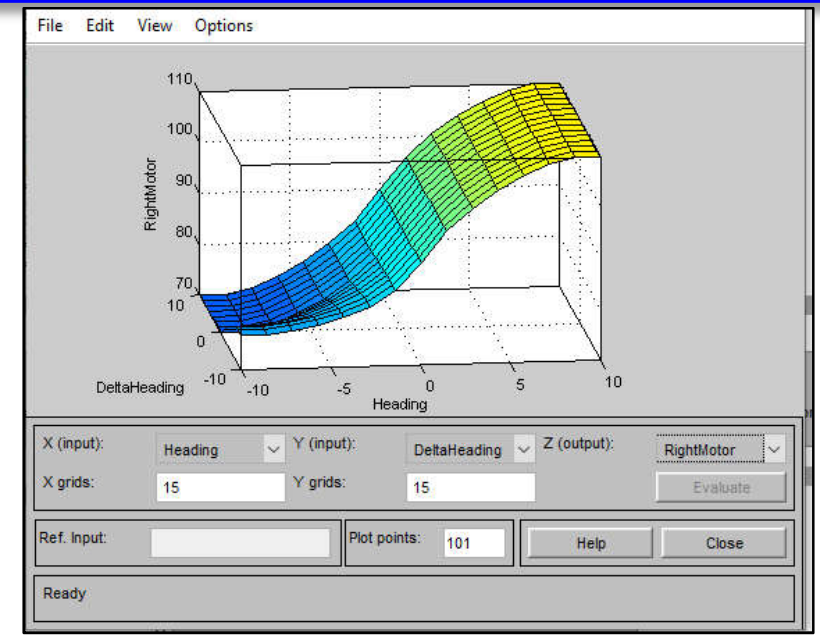

Fig. 12. Rule of Fuzzy Control Right Motor

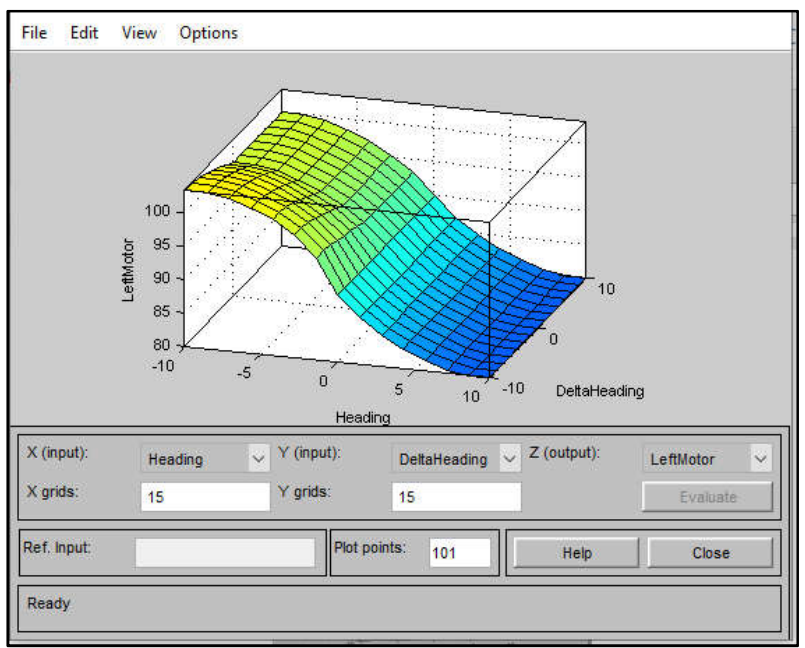

Fig. 13. Rule of Fuzzy Control on the left Motor

\section{Results and Discussion}

\subsection{Raining Mode of Waypoint Drone Hexacopter Mode}

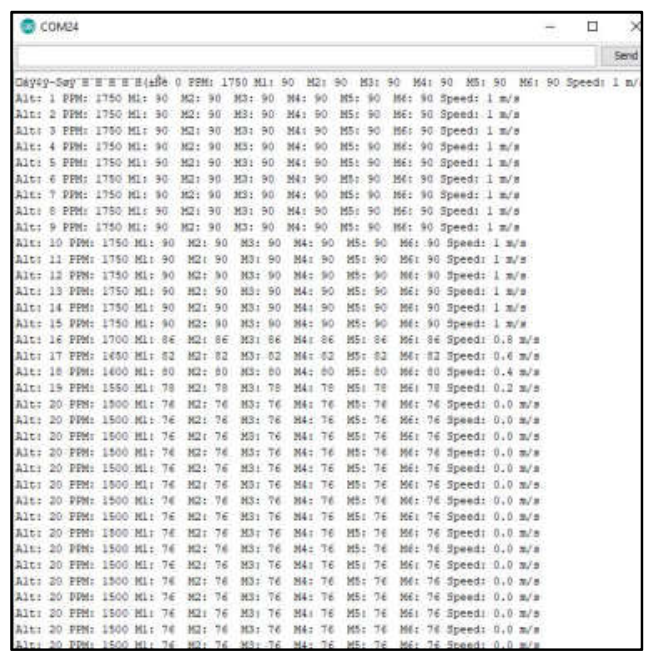

Fig. 14. Take Off Test 
Table 1. Take Off Test

\begin{tabular}{|c|c|c|c|c|c|c|c|c|}
\hline \multirow{2}{*}{$\begin{array}{l}\text { Height } \\
\text { (meters) }\end{array}$} & \multirow[t]{2}{*}{ PPM } & \multicolumn{6}{|c|}{ PWM (Motor) } & \multirow{2}{*}{$\begin{array}{c}\text { Fuzzy } \\
\text { Acceleration }\end{array}$} \\
\hline & & M1 & M2 & M3 & M4 & M5 & M6 & \\
\hline 1 & 2 & 3 & 4 & 5 & 6 & 7 & 8 & 9 \\
\hline 1 & 1750 & 90 & 90 & 90 & 90 & 90 & 90 & $1 \mathrm{~m} / \mathrm{s}$ \\
\hline 2 & 1750 & 90 & 90 & 90 & 90 & 90 & 90 & $1 \mathrm{~m} / \mathrm{s}$ \\
\hline 3 & 1750 & 90 & 90 & 90 & 90 & 90 & 90 & $1 \mathrm{~m} / \mathrm{s}$ \\
\hline 4 & 1750 & 90 & 90 & 90 & 90 & 90 & 90 & $1 \mathrm{~m} / \mathrm{s}$ \\
\hline 5 & 1750 & 90 & 90 & 90 & 90 & 90 & 90 & $1 \mathrm{~m} / \mathrm{s}$ \\
\hline 6 & 1750 & 90 & 90 & 90 & 90 & 90 & 90 & $1 \mathrm{~m} / \mathrm{s}$ \\
\hline 7 & 1750 & 90 & 90 & 90 & 90 & 90 & 90 & $1 \mathrm{~m} / \mathrm{s}$ \\
\hline 8 & 1750 & 90 & 90 & 90 & 90 & 90 & 90 & $1 \mathrm{~m} / \mathrm{s}$ \\
\hline 9 & 1750 & 90 & 90 & 90 & 90 & 90 & 90 & $1 \mathrm{~m} / \mathrm{s}$ \\
\hline 10 & 1750 & 90 & 90 & 90 & 90 & 90 & 90 & $1 \mathrm{~m} / \mathrm{s}$ \\
\hline 11 & 1750 & 90 & 90 & 90 & 90 & 90 & 90 & $1 \mathrm{~m} / \mathrm{s}$ \\
\hline 12 & 1750 & 90 & 90 & 90 & 90 & 90 & 90 & $1 \mathrm{~m} / \mathrm{s}$ \\
\hline 13 & 1750 & 90 & 90 & 90 & 90 & 90 & 90 & $1 \mathrm{~m} / \mathrm{s}$ \\
\hline 14 & 1750 & 90 & 90 & 90 & 90 & 90 & 90 & $1 \mathrm{~m} / \mathrm{s}$ \\
\hline 15 & 1750 & 90 & 90 & 90 & 90 & 90 & 90 & $1 \mathrm{~m} / \mathrm{s}$ \\
\hline 16 & 1700 & 86 & 86 & 86 & 86 & 86 & 86 & $0.8 \mathrm{~m} / \mathrm{s}$ \\
\hline 17 & 1650 & 82 & 82 & 82 & 82 & 82 & 82 & $0.6 \mathrm{~m} / \mathrm{s}$ \\
\hline 18 & 1600 & 80 & 80 & 80 & 80 & 80 & 80 & $0.4 \mathrm{~m} / \mathrm{s}$ \\
\hline 19 & 1550 & 78 & 78 & 78 & 78 & 78 & 78 & $0.2 \mathrm{~m} / \mathrm{s}$ \\
\hline 20 & 1500 & 76 & 76 & 76 & 76 & 76 & 76 & $0.0 \mathrm{~m} / \mathrm{s}$ \\
\hline
\end{tabular}

From the testing of drone can be known that when take off condition, the pulse received becomes smaller when drone position come near to point of 20 meter and velocity of drone becomes slower. If the drone keeps away from point of 20 meter so it will be stabilized at velocity $1 \mathrm{~m} / \mathrm{s}$.

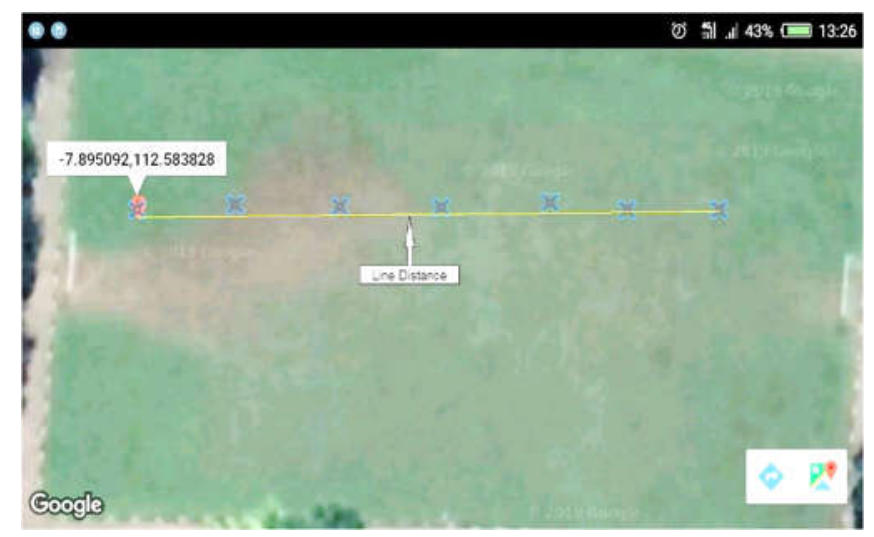

Fig. 15. Waypoint Test 
Table 2. Waypoint Test

\begin{tabular}{|c|c|c|c|c|c|c|}
\hline \multirow[t]{2}{*}{ No } & \multicolumn{2}{|c|}{$\begin{array}{l}\text { Set Up Flying } \\
\text { Coordinat }\end{array}$} & \multicolumn{2}{|c|}{$\begin{array}{l}\text { Flying coordinate } \\
\text { readings }\end{array}$} & \multirow{2}{*}{$\begin{array}{c}\text { Errror } \\
\text { Waypoint } \\
\text { (m) }\end{array}$} & \multirow[t]{2}{*}{$\begin{array}{c}\text { Fuzzy } \\
\text { Acceleration }\end{array}$} \\
\hline & Latitude & Longtitude & Latitude & Longtitude & & \\
\hline 1 & -7.895092 & 112.584507 & -7.895092 & 112.584507 & 0 & $0 \mathrm{~m} / \mathrm{s}$ \\
\hline 2 & -7.895089 & 112.584410 & -7.895089 & 112.584410 & 0 & $0 \mathrm{~m} / \mathrm{s}$ \\
\hline 3 & -7.895089 & 112.584317 & -7.895085 & 112.584310 & 0.8 & $0.8 \mathrm{~m} / \mathrm{s}$ \\
\hline 4 & -7.895092 & 112.584189 & -7.895090 & 112.584183 & 0.7 & $0.7 \mathrm{~m} / \mathrm{s}$ \\
\hline 5 & -7.895088 & 112.584071 & -7.895089 & 112.584065 & 0.6 & $0.6 \mathrm{~m} / \mathrm{s}$ \\
\hline 6 & -7.895090 & 112.583941 & -7.895087 & 112.583943 & 0.4 & $0.4 \mathrm{~m} / \mathrm{s}$ \\
\hline \multirow[t]{2}{*}{7} & -7.895092 & 112.583828 & -7.895092 & 112.583828 & 0 & $0 \mathrm{~ms}$ \\
\hline & & & & & 0.4 & $0.4 \mathrm{~m} / \mathrm{s}$ \\
\hline
\end{tabular}

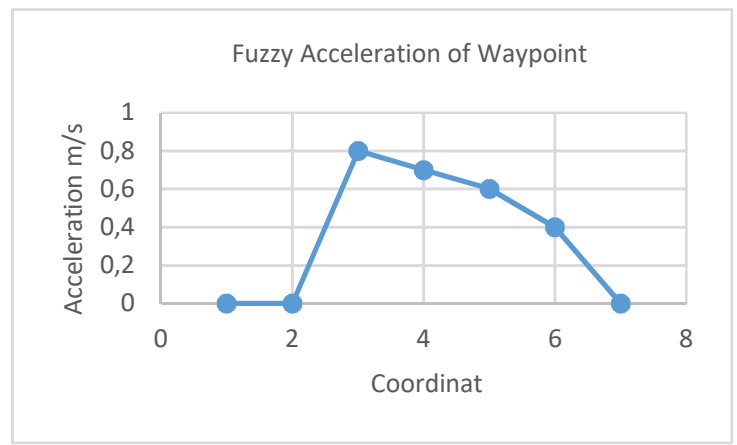

Fig. 16. Fuzzy Acceleration of Waypoint

From the testing aplication of fuzzy logic at the waypoint mode, the average results of errors at reading of coordinate is 0,4 meter from line distance that is given and response acceleration of fuzzy to reset the drone back to the distance of $4 \mathrm{~m} / \mathrm{s}$. From steps of the small errors so can be summarized that from the seven point provided rules of fuzzy logic can help navigation and make movement of drone smooth for coordinates destination. that is the picture of acceleration fuzzy logic at waypoint chart. It represents with Fig. 16

\section{Conclusion}

The results of planning, making and testing of applications, the conclusions can be drawn. These conclusions include: (a). Control of the stability of the drone system in the air is obtained by processing GPS sensors with the fuzzy logic method with an error at reading of coordinate is 0,4 meter from line distance that is given and response acceleration of fuzzy to reset the drone back to the distance of $4 \mathrm{~m} / \mathrm{s}$. (b). of the error value that is given gives an effective response but there are still a few deficiencies due to rules that need to be adjusted. 


\section{References}

[1] D. Puspitaningrum, "Pengantar jaringan syaraf tiruan,” 2006.

[2] A. Maria, "Penggunaan jaringan syaraf tiruan backpropagation untuk seleksi penerimaan mahasiswa baru pada jurusan teknik komputer di Politeknik Negeri Sriwijaya.” Diponegoro University, 2013.

[3] N. Yanti and T. Nur, "APLIKASI JARINGAN SYARAF TIRUAN PADA SISTEM KONTROL ROBOT LINE FOLLOWER DENGAN ALGORITMABACKPROPAGATION," Pros. SNITT POLTEKBA, vol. 2, no. 1, pp. 270-276, 2017.

[4] A. Widiyanto and N. Nuryanto, "Rancang Bangun Mobil Remote Control Android dengan Arduino," Creat. Inf. Technol. J., vol. 3, no. 1, pp. 50-61, 2015.

[5] Y. Afriansyah, R. Arifuddin, and Y. Novrianto, "Rancang Bangun Alat Pendeteksi Detak Jantung, Suhu Tubuh, dan Tensimeter Berbasis Arduino Uno serta Smartphone Android," SinarFe7, vol. 1, no. 2, pp. 597-603, 2018.

[6] P. D. P. Adi and R. Arifuddin, "Design Of Tsunami Detector Based Sort Message Service Using Arduino and SIM900A to GSM/GPRS Module," JEEMECS (Journal Electr. Eng. Mechatron. Comput. Sci., vol. 1, no. 1, pp. 1-4, 2018.

[7] A. Kadir, "Panduan Praktis Mempelajari aplikasi mikrokontroler dan pemrogramannya menggunakan Arduino." Penerbit Andi, 2013.

[8] A. N. G. O. Son Kuswadi, M. N. Tamara, and S. Indra Adji, “Optimasi Sistem Navigasi Robot Bencana dengan Algoritma Bug dan Jaringan Syaraf Tiruan,” J. Teknol. Inf. dan Ilmu Komput., vol. 5, no. 5, 2018. 